\title{
Our Vice-Presidents among Their Books
}

\author{
LESLIE W. D UNLAP
}

Since the formation of the government of the United States in April of 1789,43 men have held the office of vice-president. Under the Constitution the vice-president presides over the Senate but does not vote except to break a tie, and, in the event of the death, resignation, or inability of a president to serve, the "Powers and Duties" of his office "shall devolve on the Vice President." Of the 43 vice-presidents, 13 became president, 4 of whom (Adams, Jefferson, Van Buren, and Nixon) were elevated through regular elections.

Although Indiana claimed in the early twentieth century to be "the mother of vice-presidents," the honor belongs to New York, the official residence of 11 vice-presidents. Indiana and Massachusetts are tied for second with 4 vice-presidents each; Kentucky and Texas each furnished 3; and three states, Virginia, Illinois, and Minnesota, were the homes for 2. The remainder came from 12 different states as far apart as Maine and California.

More than two-thirds of our vice-presidents (30), have been lawyers, a book-based profession that depends on statutes, codes, and judicial interpretations thereof; and slightly more than two-thirds of the 43 (30 again) attended college for at least a few years. Before World War I, a college education ordinarily required considerable familiarity with ancient languages and, in church-related schools, with the Scriptures. Many of the vice-presidents who attended college left after a year or two to begin the study of law under a seasoned practitioner. Three of our vice-presidents attended Harvard; and the College of William and Mary, Yale, Centre College in Danville, Kentucky, and the University of Minnesota were each attended by 2 future vice-presidents. The 19 other vice-presidents who attended college did so at different institutions, 9 of which are located in New England or in the Middle Atlantic States.

At least 4 of our vice-presidents developed a passion for books. The first 2, Adams and Jefferson, were lawyers; Theodore Roosevelt was a rancher and writer; and Harry Truman was a successful machine politician. Of the 4, 3 attended college: 2 (Adams and T. Roosevelt) at Harvard, and 1 (Jefferson) at the College of William and Mary. The 
formal education of the fourth (Truman) ended with graduation from high school.

While at Harvard, John Adams developed "a growing curiosity, a Love of Books, and a fondness for Study," which became one of his strongest traits. In 1772 while riding the legal circuit as a young lawyer, John Adams became annoyed with his "wandering, itinerating life," and he longed for the sights and sounds of home. He missed his "Grass and Blossoms and Corn," but, above all, Adams wrote, "except the Wife and Children, I want to see my books." According to Dr. Benjamin Rush, colonial physician and scientist, "Every member of Congress in 1776 acknowledged him [Adams] to be the first man in the House"; his thorough approach to knotty problems brought Adams the chairmanship of 25 committees in the Second Continental Congress. As vice-president, Adams observed, "The more one reads the more one sees we have to read."

In his eighties the former vice-president and president was overwhelmed with many books which came from "Friends . . , or Enemies." Adams plaintively queried friend Thomas Jefferson, "What should I do, with all this lumber?" The old patriot in Quincy depended on the women in his household to read aloud his new books in English, but he had "to excruciate my Eyes" on the books in French. "And all to what purpose?" queried the crusty old man, "I verily believe I was as wise and good, seventy years ago, as I am now."

Our second vice-president, Thomas Jefferson, was a truly remarkable bookman. At age 28 Jefferson responded to the request of another Virginia gentleman for guidance in the choice of books which would be "improving as well as amusing." Although Jefferson's correspondent lacked "leisure for any intricate or tedious study," the young sage of Monticello furnished a list of 148 titles in 379 volumes which would cost about four times the amount his friend intended to spend. Jefferson's list contained the titles of well-known works in criticism, politics, religion, history, and natural science with a generous selection of literary classics, especially the plays and novels of English writers of the seventeenth and eighteenth centuries. Presumably young Jefferson had read all of the books on his list, an eighteenth-century precursor of the Harvard "Five-foot shelf" and Will Durant's list of the world's 100 "best books."

During his long and active life, Jefferson formed three important personal libraries. The first was burned in 1770 in the fire which consumed his mother's mansion, and Jefferson at age 27 started anew. Within three years he acquired 1,250 books, not including volumes of music and his "books in Williamsburg." This was the beginning of his "Great Library," which was purchased in 1815 by Congress to replace 
the collection of the Library of Congress destroyed a year earlier by British troops. After his books had been packed and shipped to Washington, Jefferson commissioned George Ticknor to buy in Europe editions of the classics he wanted close at hand. For, as the former vice-president and president wrote on June 10,1815, to John Adams, "I cannot live without books." Jefferson's third collection was bequeathed to the University of Virginia but had to be sold in Washington in 1829 to relieve some of the encumbrances on his estate.

In addition to forming three personal libraries, Jefferson in his eighties had a dominant role in forming the library collection for the new University of Virginia, which was to be opened in 1825. Although Jefferson was feeble from old age and his wrist was stiff from an accident "about 30 years ago," he prepared with care the list of books to be ordered. "In general," wrote Jefferson to his bookdealers in Boston on November 4, 1825, "I wrote the title in the language desired, but where I did not understand the language, I was not always exact in doing that." In the midst of his exchanges with the Boston firm, Jefferson, two months before his death, included "a private application" for three titles wanted for his third personal collection. The books Jefferson ordered for himself were an encyclopedia of gardening, a history of the Anglo-Saxons, and an edition of Theocritus in both Greek and Latin!

Theodore Roosevelt devoured books, and he recognized that "reading with me is a disease." As president he read at least a book a day, and in evenings when there was no official entertainment, he would read two or three complete volumes. In a single year in the White House, Roosevelt read through all the novels of Trollope, the complete works of De Quincy, the prose works of Milton and Tacitus, and the poetry of Scott, Poe, and Longfellow, "not to mention at least 500 other volumes, on subjects ranging from tropical flora to Italian naval history." When he read a periodical, he would tear out a page he had finished and throw it onto the floor; after the issue (or issues) had become a pile of crumpled paper, Roosevelt would leap from his rocking chair and stride down the corridor to his bedroom.

The man was a human dynamo. While an undergraduate at Harvard, young Roosevelt formed a lifelong friendship with Owen Wister, author of The Virginian. Roosevelt, according to Wister, was charged with high "voltage." Shortly before an evening crowded with entertainment at the White House, Wister loaned the president a book of more than 300 pages and was surprised to hear at breakfast the next morning a complete review of the work. Roosevelt's extraordinary memory enabled him to retain, even to quote, much of what he had read, and his ability to weave 
bits of information culled from his extensive reading into his conversations helped him to obtain a reputation for wide and deep culture.

Roosevelt did not approach his reading with detachment but tested the works he read against his own stern moral code. Tolstoy was condemned because he had "preached against war ... as against marriage," and Dickens had failed to see the "real greatness ... all around him here in America." Emile Zola was banished completely, for his works contained "conscientious descriptions of the unspeakable."

President Roosevelt enjoyed his reading of Edwin Arlington Robinson's The Children of the Night, and he wrote the poet a complimentary note and penned a review for the Outlook in which he perceived in Robinson's work "a little of the light that never was on land or sea." In order to help the promising poet who had been trying to write advertising in Boston, the President appointed Robinson to a sinecure in the New York Custom House, truly an extraordinary example of patrician patronage in a democracy.

Harry Truman's mother, who had attended the Baptist Female College in Lexington, Missouri, taught her son to read before he was 5, and he read the Bible through several times before he reached 12. Harry's need to wear heavy glasses and his slow recovery from a case of diphtheria kept the boy from participation in sports; instead, he reveled in the histories and biographies obtainable from the local public library.

After Harry Truman finished the Independence High School in 1901, he worked for four years in banks in Kansas City where he continued to read in favorite fields. At age 21, Harry Truman, along with "some of the boys in the bank," joined the Missouri National Guard. He explained that he did so deliberately.

After reading all the books obtainable in the Independence and Kansas City libraries on history and government from Egypt to U.S.A., I came to the conclusion that every citizen should know something about military, finance or banking, and agriculture. So I started my grass roots military education by joining a National Guard battery, June 14, 1905.

Much of the knowledge of the past that Truman had obtained through reading he retained as an adult, and he tried to stimulate in his daughter Margaret an interest in learning. While in the Senate, Truman wrote to the 13-year-old girl in Independence encouraging her to apply herself to her studies including history, music, French, geography, and mathemat- 
ics. Someday, Margaret's father counseled, "you'll be very glad that you can ... talk intelligently about Agrippa and Genghis Khan!"

As president, Truman was confronted with many serious problems for which he had no real background, and he drew on the past for help. After he left office he explained how he had reached many important decisions.

I was always thinking about what was pending and hoping that the final decision would be correct. I thought about them on my walks. I thought about them in the morning and the afternoon and thought about them after I went to bed and then did a lot of reading to see if I could find some background of history which would affect what had to be done.

The importance of reading history and biography for leaders in a democracy loomed even larger in Truman's mind after he retired to Independence, Missouri, and observed the formation of the Truman Presidential Library. He visited the library and museum almost daily, and on one occasion in 1960 he spoke earnestly to a group of schoolchildren who had come to see the institution and to meet the former president.

Readers of good books, particularly books of biography and history, are preparing themselves for leadership. Not all readers become leaders. But all leaders must be readers.

Political leaders like publicity. It does them little good unless the historical background is there to support the publicity. No one ever loses by reading history, great literature---and even newspapers. [Truman believed he had often been treated unfairly by the press.]

Four of our vice-presidents (Fillmore, Colfax, Stevenson, and Dawes) who do not seem to have been afflicted with bibliomania amassed libraries of considerable size. The first of these, Millard Fillmore, read voraciously as a youngster to enlarge his fund of knowledge, and he continued as an adult to be an avid reader. Fillmore visited bookstores wherever he found them, and on trips to New York City he returned with books under his arm. As need arose, his wife, Abigail, would call in a carpenter to build more bookcases until the Fillmores' collection numbered 4,000 volumes.

Although Fillmore's persistence in book collecting should entitle him to be bracketed with the four vice-presidents who shared a passion for books, his interest in his collection seems to have been principally another facet of his lifelong involvement in cultural activities in the rapidly growing city of Buffalo. Fillmore worked for the Young Men's Association in his adopted city, for the embryonic local historical society, for the recently endowed Grosvenor Library, and for the newly established medical college of the projected University of Buffalo. His collection contained many government reports and other publications valuable only for the information they contained; "there were few books 
of monetary value, and fewer yet that were rare." "It was in no wise a notable library," wrote the editor of the Fillmore papers in two volumes published by the Buffalo Historical Society (1907).

Before Fillmore's collection was sold in 1890 at an auction in Buffalo, a catalog of 50-odd pages was prepared. Again, according to the editor of his papers, Fillmore's library "is pathetic in its arid lack of poetry, of belles lettres, of well nigh everything that breathes of beauty and of spirit." Fillmore deserves high marks for his persistence in bringing books together, but he was deficient in his literary appreciations. No true bookman would claim, as Fillmore did, that Shakespeare was overrated; the largely self-educated man in Buffalo found Alexander Pope's An Essay on Man more to his liking.

Schuyler Colfax, the only newspaper man to become vice-president, was a reporter and publisher before he was elected in 1856 to Congress. He earned his sobriquet, "Smiler," for he never lost a friend or made an enemy; however, leading contemporaries in Washington who knew him well considered Colfax to be a man of small capabilities. Midway in his term as vice-president, Colfax announced that he would not seek reelection; he may have hoped to replace President Grant at the end of his first term and he felt a need to obtain more money. Near the end of his four years as vice-president, Colfax was named among those who had accepted stock from the company which had undertaken to build the Union Pacific Railroad.

Colfax's first wife had died in 1863, and in the month of his election to the vice-presidency, November 1868, he married Nellie Wade, the attractive niece of a radical Republican senator from Ohio. Their son, Schuyler Colfax III, was born in April 1870, and three years later the Colfaxes moved into his family's large two-story frame house in South Bend, Indiana. The house contained a private library of 1,600 volumes, but Schuyler's subsequent use of it could not have been heavy. Colfax soon found the lecture platform to be a better source of income than newspaper work or politics; and in the 12 years before his death, he gave an estimated 1,000 lectures on popular topics, an average of 7 per month. His wife understandably wondered when her husband would decide to remain at home with his family and books, but he continued to accept invitations to speak and died of a heart attack in subzero weather between railway stations in Mankato, Minnesota, on his way to an engagement in northwestern Iowa.

Both of our vice-presidents who resided in Illinois formed libraries of considerable, yet unrecorded, size. Adłai E. Stevenson, vice-president during President Cleveland's second term, is remembered today principally as the grandfather of his namesake who ran twice unsuccessfully as 
the Democratic candidate for president against Dwight Eisenhower. After the first Adlai Stevenson concluded his term as vice-president from 1893 to 1897 , he returned to Bloomington, Illinois, where he had many friends and a lucrative law practice. He and his wife lived in a large Victorian house where the elder statesman could romp with his grandchildren and enjoy his large library. The collection was rich in works on history and Shakespeare and probably proved useful to the former vice-president in the preparation of his volume of reminiscences entitled Something of Men I Have Known.

Charles G. Dawes, vice-president during Coolidge's term as an elected president, 1925-1929, was born and educated in Ohio. During his twenties, Dawes married Caro Blymer, whom he had known in Cincinnati, and the couple established a home in Lincoln, Nebraska, where Charles had begun the practice of law. During his years in Lincoln, Dawes read widely and formed lifetime friendships with William Jennings Bryan and John J. Pershing.

In 1894, Dawes purchased the Northwestern Gas, Light and Coke Company at Evanston, Illinois, and in 1895 he moved his family to Chicago. In 1909 Dawes and his wife bought a large Victorian house in Evanston, which had space for a sizable collection of books. Dawes's career overseas in World War I and in government service in Washington was distinguished by notable accomplishments, and he and his family could not settle into their spacious home until Dawes returned in the summer of 1932 to Chicago to stay. In 1942 Dawes deeded his home with his books and papers to nearby Northwestern University with the proviso that he and his wife would continue to use the property in their lifetimes. The former vice-president died in his library on April 23, 1951, and his wife of 62 years lived on in their home until October 3, 1957.

At least 6 of the 43 vice-presidents have library memorials in their honor. The widow of Thomas A. Hendricks, vice-president during President Cleveland's first term until his death in 1885, donated in 1903 $\$ 25,000$ to his alma mater, Hanover College in Indiana, to build a library in his honor. Another Hoosier, Thomas Marshall, vice-president during President Wilson's two terms, was devoted throughout his life to Wabash College in Crawfordsville, Indiana, where a room in the college library was named as the repository for his books and papers. Also, a Coolidge Room in the Northampton, Massachusetts, public library was dedicated in 1956 in honor of the man who began his political career in the town as its mayor and lived there before and after his years in Washington, D.C. The three other libraries that bear the names of former vicepresidents are presidential libraries erected and maintained to house the papers and memorabilia pertaining to the careers and administrations of 
Presidents Truman (Independence, Missouri), Lyndon Johnson (Austin, Texas), and Ford (Ann Arbor and Grand Rapids, Michigan).

At least 8 of our 43 vice-presidents wrote books other than memoirs or autobiographies. The first of the eight was our first vice-president, John Adams, who, while serving the Continental Congress as a diplomat in Europe, wrote his Defence of the Constitutions of Government. Therein Adams describes the governments of numerous European states and draws on political thinkers, ancient and modern, in order to defend the constitutions of certain American colonies. Adams objected to the unicameral legislature he had observed in France; and, as a conservative, he favored bicameral legislatures and the sharing of power among the legislative, executive, and judicial branches of a government. The first volume of Adams's Defence was published in January of 1787 in London and was reprinted several times in the American colonies during the discussions of the Constitutional Convention that met in May of 1787. Many of the ideas Adams favored were embodied in the new American Constitution, and the publication of the first volume of his Defence probably helped to foster a citizenry in favor of a form of government that utilized a bicameral legislature and distributed power among its principal branches.

Thomas Jefferson wrote little of consequence for publication besides his Notes on the State of Virginia, a scientific compilation which reveals many of its author's philosophic views. Nevertheless, Jefferson's rank as a writer is very high, because he was the principal author of the eloquent Declaration of Independence and is rightly recognized as a master of the congenial art of letter writing.

As a young congressman from South Carolina, John C. Calhoun favored the development of a strong national government, but he came to realize that a tariff for protection as distinguished from a tariff for revenue was ruinous to the South. In order to defend his agrarian region against the dominance of big business and big government, Calhoun wrote his South Carolina Exposition (1828) in which he developed several doctrines, including nullification, to thwart the "Tariff of Abominations." As the division between the North and the South widened over the expansion of slavery into the newly acquired territories, Calhoun wrote his Disquisition on Government (1849) and his Discourse on the Constitution (1850) in which he retreated from his earlier positions on nullification and states' rights. In their place Calhoun argued for a recognition of the rights of large constituencies in the country (such as the agrarian South) as opposed to the rule of a simple majority. The triumph of the last, Calhoun believed, would bring the end of slavery and 
would place the economy of the South under the dominance of an industrial North.

Henry Wilson, vice-president during President Grant's second term, was born into a poverty-stricken family named Colbath, and at age 10 he was bound out to a New Hampshire farmer. At age 21 Jeremiah Colbath took the name Henry Wilson and walked from Farmington, New Hampshire, to Natick, Massachusetts, to learn the trade of shoemaking. Wilson's manufacture of inexpensive work shoes prospered, and he could afford to turn to politics for a second career. With a sixth sense of what the voters in Massachusetts would support, Wilson moved from party to party but was constant in his opposition to slavery. After he became vice-president, Wilson aspired to succeed Grant as president, and he strove to complete his compilation in three volumes entitled History of the Rise and Fall of the Slave Power in America. Paralytic strokes cut him down, and the one-time cobbler died in office on November 22, 1875.

The only vice-president who could be called a professional writer was Theodore Roosevelt, the author of 23 books of history, biography, natural history, political philosophy, and essays. In addition, Roosevelt wrote numerous articles and reviews, many of which have merit but many were hackwork because he needed money to support his family in a mansion on Long Island. Roosevelt felt a compulsion to write which he did with verve when he was in the mood, yet he complained, "Writing is horribly hard work to me." In the midst of writing his final chapters of The Winning of the West, Roosevelt realized, "I would like above all things to go into politics." Although the quality of some of his work as a historian and biographer is poor, the quantity is large, indeed, for a man who enjoyed his family, moved in society, held important political offices, traveled and lived in the West, and possessed expertise in an extraordinary range of fields.

Roosevelt's first historical work, The Naval War of 1812, was begun while he was a senior at Harvard and was completed at age 23. In the preparation of this work, young Roosevelt examined quantities of technical records, and he produced a book that was recognized at once as an important contribution to naval history. After this initial success, Roosevelt wrote lives of Thomas Hart Benton and Gouverneur Morris for the American Statesmen Series which evoked mixed reviews.

Roosevelt yearned to produce a historical work of the first rank, and he undertook to tell the history of the expansion of the United States west of the Appalachian Mountains in the late eighteenth and early nineteenth centuries. In the midst of his other activities, Roosevelt worked on his project for nine years and completed four of the planned seven volumes. 
Roosevelt took for his models the narrative histories of Parkman and Prescott, and he succeeded admirably. After he had consulted original documents in archives and libraries, Roosevelt wanted his readers to smell the smoke from a settler's log cabin and to hear the snap of dry twigs beneath the boot of a heroic frontiersman. His work was read and praised by both laymen and professional historians in this country and in England.

At the other extreme is Roosevelt's Oliver Cromwell, his thirteenth book and third biography, which he undertook while governor of New York. He intended to write the book within a free month, but political obligations invaded his meager allotment of time. According to his secretary, Roosevelt would appear each morning with a pad full of notes and one or two reference books and would dictate "with hardly a pause." On one occasion, Roosevelt called in a second stenographer and dictated gubernatorial correspondence in between paragraphs of his biography "while a barber tried simultaneously to shave him." Roosevelt did no new research for his Cromwell, but he did produce within a few weeks 63,000 words of readable prose. The completed book did not compare favorably with the lives of Cromwell published earlier, and one wonders what inner compulsion drove Roosevelt as governor to write in haste a book which he knew would bring him little credit.

In 1933 when Henry Wallace, plant scientist and editor of Wallaces' Farmer, was invited by President Franklin D. Roosevelt to head the Department of Agriculture, he seized the opportunity to work "under a chief who is definitely progressive, entirely sympathetic toward agriculture, and completely determined ... to restore farm buying power." Wallace moved into his new office as a man possessed by a mission: in his first year as secretary of agriculture, he traveled through 48 states, made 88 speeches, and wrote 20 articles and 3 books. He supported President Roosevelt wholeheartedly and became a leading spokesman for the untested philosophies of the New Deal.

During his terms as vice-president and secretary of commerce, Wallace advocated the economic improvement of people in all countries through a strong world organization. The advanced positions he held often developed into books: Agricultural Prices (1920), New Frontiers (1934), Century of the Common Man (1943), and Sixty Million Jobs (1945). Wallace's sympathies toward the Soviet Union conflicted with President Truman's decision to assist countries trying to resist Communist aggression. After President Truman asked Wallace for his resignation, the dreamer of utopias moved to a farm in South Salem, New York, from which he could commute to Manhattan to work as an editor for the New Republic. Instead of confining his interests to agricultural experiments 

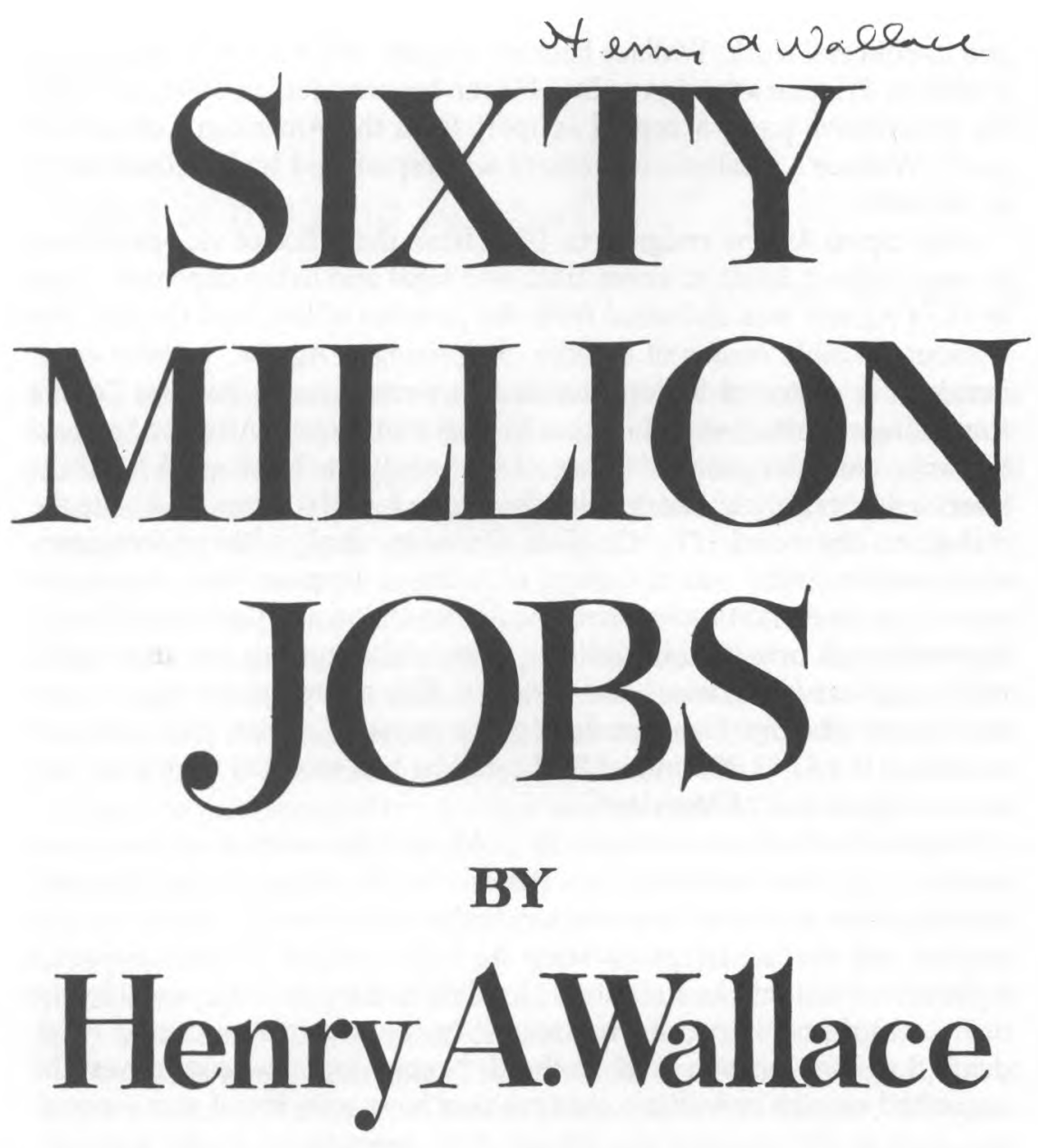

¿ This book is a philosophy of freedom; a declaration of American interdependence, a program for full employment written by one of the great Americans of our time. It shows why sixty million jobs and a two hundred billion dollar annual income by $195^{\circ}$ are essential to preserve our free enterprise system. It shows how these objectives can and must be realized.

The cover of Vice-President Henry A. Wallace's Sixty Million Jobs (New York: Simon and Schuster, 1945) with Wallace's signature in the upper right. 
and to editorial work, Wallace became a leader of the liberals opposed to President Truman's foreign policy. He ran for president in 1948, but after his Progressive party accepted support from the American Communist party, Wallace's idealistic movement was repudiated by his countrymen at the polls.

After Spiro Agnew resigned in 1973 from the office of vice-president, he was without funds to cover fines and legal and living expenses. Early in 1974 Agnew was disbarred from the practice of law, and this left him without a visible means of income. Surprisingly, Agnew, without experience as a writer of fiction, decided to write a novel because "doing something creative" would restore his lost confidence. After he had told his wife, daughter, and secretary of his intention, he worked for three hours a day writing his story in longhand; he found it easier to dictate the dialogue. The novel, The Canfield Decision, dealt with an imaginary vice-president who was the dupe of militant Iranians who wanted to provoke a confrontation between the Soviet Union and the United States. Agnew's book brought him ridicule from critics but not less than half a million dollars in advances and royalties. This approximates the amount the former vice-president needed to pay damages, taxes, and legal fees related to the $\$ 147,000$ in kickbacks that he had received during his two years as governor of Maryland.

Walter Mondale, as a senator from Minnesota, wrote a curious book entitled The Accountability of Power. In his introduction Mondale explains that the book was an expansion of a Senate speech on the subject and that in its preparation he had received assistance from a legislative assistant. As a senator, Mondale had become disturbed by the drift toward an "Imperial Presidency" in the administrations of Presidents Lyndon Johnson and Richard Nixon, and, as correctives, he suggested certain unrealistic changes that have won few if any supporters, such as the repeal of the Twenty-fifth Amendment to the Constitution.

Eleven of our 43 vice-presidents wrote autobiographical works which were published in book form. The first of these was Adlai Stevenson's Something of Men I Have Known (1909), and three others (works by Marshall, Coolidge, and Dawes) appeared early in the present century. Since the publication in 1954 of Alben Barkley's That Reminds Me, there has been a steady stream of autobiographical books by former vicepresidents (Truman, Nixon, L. B. Johnson, Humphrey, Agnew, and Ford). Walter Mondale has not furnished an autobiography, but his running mate in 1984 did so in 1985 . Geraldine Ferraro, the first woman to be nominated by a major political party for the vice-presidency, completed with help from a collaborator a volume entitled Ferraro, My Story. 